\title{
Analisis Faktor-faktor yang Memengaruhi Tingkat Kepatuhan Membayar Zakat: Studi Kasus Kabupaten Bogor
}

\section{Analysis of Factors Affecting Compliance Level of Paying Zakat: A Case Study in Bogor Regency}

\author{
Ahmad Mukhlis dan Irfan Syauqi Beik \\ Alumni Program Studi Ekonomi Studi Pembangunan (ESP) FEM IPB \\ Ketua Program Studi Ilmu Ekonomi Syariah, Departemen Ilmu Ekonomi FEM IPB
}

\begin{abstract}
Poverty is one of major problems faced by Indonesia. The economic crisis occured within the country and around the world has lengthened the poverty disaster attacking Indonesia. To overcome these problems, zakat is likely to be an alternative solution that can be utilized by government. Zakat is a means legalized by Islam in capital formation. Capital formation is not solely based on utilization and development of natural resources, but also from obligatory contributions of the rich. Zakat is also playing significant role in improving the quality of human resources and the provision of facilities and infrastructure of production. The potential zakat of Indonesia exceeds Rp 217 trillion, but in reality the absorption of zakat funds reached Rp 1.5 trillion in 2010. The huge gap between the potential and the actual collection of zakat indicates that there are some Muslims who are less motivated to pay zakat. The purpose of this study is to identify factors that affect compliance level of paying zakat, and to identify the dominant factors, in order to more easily create optimal policy. Results from this study are expected to help increase acceptance of zakat, both at central and regional levels. Data is collected through a survey of 100 respondents in Bogor regency. The analytical method used is factor analysis. The program used to analyze the data is SPSS Statistics 17 for Windows. From these results, it is known that factors affecting willingness to pay the zakat are: religious factors, such as faith, religious understanding, and rewards; and other factors such as social awareness, self-satisfaction, and organizations. This also gives guidance that in order to increase zakat revenue, emphasis not only on religious aspect, but also on social, self-satisfaction, and organization aspects is very important. Among the variables that affect compliance level of paying zakat is the role of amil organization (OPZ). OPZ professionalism can strengthen regularity of zakat payer to pay zakat at OPZ. Improving the quality of OPZ in terms of transparency, socialization, and administration, will significantly affect the preferences of zakat payers to fufill their obligation at the amil institutions.
\end{abstract}

Keywords: Potential of zakat, factor analysis, zakat institution

Abstrak. Kemiskinan merupakan permasalahan utama di Indonesia. Krisis ekonomi yang terjadi di dalam negeri maupun di luar negeri ikut memengaruhi lamanya bencana kemiskinan yang menimpa Indonesia. Untuk mengatasi permasalahan ini, zakat dapat menjadi alternatif program pemerintah. Zakat merupakan sarana yang dilegalkan oleh agama Islam dalam pembentukan modal. Pembentukan modal tidak semata-mata dari pemanfaatan dan pengembangan sumber daya alam, akan tetapi juga berasal dari sumbangan wajib orang kaya. Zakat juga berperan penting dalam peningkatan kualitas sumber daya manusia dan penyediaan sarana dan prasarana produksi. Potensi zakat yang dimiliki oleh Indonesia melebihi Rp 217 triliun, namun pada kenyataannya penyerapan dana zakat baru mencapai Rp 1,5 triliun pada tahun 2010. Terjadinya gap yang besar antara potensi zakat dan nilai zakat yang terkumpul mengindikasikan ada sebagian orang Islam yang kurang termotivasi untuk membayar zakat. Tujuan dari penelitian ini adalah untuk mengidentifikasi faktor-faktor yang memengaruhi kepatuhan membayar zakat, dan untuk mengidentifikasi faktor yang dominan, agar lebih mudah dalam membuat kebijakan yang optimal. Hasil dari studi ini diharapkan dapat membantu meningkatkan penerimaan dana zakat, baik di pusat maupun di daerah. Pengumpulan data dilakukan melalui survey terhadap 100 orang responden di wilayah Kabupaten Bogor. Metode analisis yang digunakan adalah menggunakan alat analisis faktor. Program yang digunakan untuk melakukan olah data ini adalah SPSS Statistics 17 for windows. Dari hasil penelitian ini, diketahui sejumlah faktor yang membuat seseorang mau untuk membayar zakat adalah faktor keagamaan seperti iman, pemahaman agama, dan balasan, lalu ada juga faktor-faktor lainnya seperti kepedulian sosial, kepuasan diri, dan organisasi. Hal ini sekaligus memberikan arahan bahwa untuk meningkatkan penerimaan zakat, tidak hanya menekankan aspek keagamaan, tetapi ikut memerhatikan aspek sosial, kepuasan diri, dan organisasi. Diantara hal yang 
memengaruhi kepatuhan membayar zakat adalah adanya peran dari Organisasi Pengelola Zakat (OPZ). Keprofesionalan OPZ dapat membuat wajib zakat lebih patuh untuk membayar zakat di lembaga tersebut. Dengan meningkatkan mutu pelayanan OPZ seperti dalam hal transparansi, sosialisasi, dan administrasi, maka preferensi responden dalam membayar zakat di lembaga tersebut akan semakin meningkat.

Kata Kunci: Potensi zakat, analisis faktor, organisasi pengelola zakat

\section{PENDAHULUAN}

Kemiskinan yang terjadi di Negara Indonesia sudah berlangsung sejak lama. Krisis ekonomi yang terjadi di dalam negeri maupun di luar negeri ikut memengaruhi lamanya bencana kemiskinan yang menimpa Indonesia.

Zakat sangatlah mungkin menjadi alternatif program pemerintah sebagai sumber dana untuk mengatasi kemiskinan (Ibrahim, 2006). Zakat merupakan sarana yang dilegalkan oleh agama Islam dalam pembentukan modal. Pembentukan modal tidak semata-mata dari pemanfaatan dan pengembangan sumber daya alam, akan tetapi juga berasal dari sumbangan wajib orang kaya. Zakat juga berperan penting dalam peningkatan kualitas sumber daya manusia dan penyediaan sarana dan prasarana produksi (Miftah, 2008).

Pada periode 2007 - 2010, pertumbuhan rata-rata dana zakat yang diterima oleh Badan Amil Zakat Nasional (BAZNAS) adalah sebesar 53,29 persen seperti yang dijelaskan pada Tabel 1. Dilihat dari sisi total zakat yang diterima, nilai tersebut pada dasarnya masih jauh lebih kecil jika dibandingkan potensi yang seharusnya terkumpul yaitu sebesar Rp 217 triliun (Hasil penelitian FEM IPB dan BAZNAS).

Tabel 1. Total zakat yang diterima oleh BAZNAS periode 2007-2010

\begin{tabular}{|c|c|c|}
\hline Tahun & $\begin{array}{c}\text { Total Zakat } \\
\text { (Miliar Rupiah) }\end{array}$ & $\begin{array}{c}\text { Pertumbuhan Tahunan } \\
(\%)\end{array}$ \\
\hline 2007 & 450 & - \\
2008 & 920 & 104,44 \\
2009 & 1200 & 30,43 \\
2010 & 1500 & 25,00 \\
\hline
\end{tabular}

Sumber: BAZNAS 2010 (diolah)

Manfaat zakat tidak hanya sebagai pembentuk modal, zakat dapat mengatasi masalah penumpukan harta di kalangan tertentu dalam kehidupan bermasyarakat, sehingga jurang pendapatan antar golongan di masyarakat dapat diminimalisir sebagaimana hasil riset yang pernah dilakukan oleh Ismail Salleh, Rogayah Nagah, dan Jehle. Mereka mengadakan kajian tentang pengaruh zakat terhadap distribusi pendapatan, hasilnya bahwa zakat memberikan efek postif dalam mengurangi ketidakseimbangan pendapatan (Ibrahim, 2008).

Syauqi Beik dalam Shalihati (2010) menemukan bahwa program zakat untuk usaha produktif mustahik fakir miskin, mampu mengurangi kemiskinan mustahik sebesar 7,5 persen di Jakarta. Selain itu tingkat kedalaman dan keparahan kemiskinan mustahik juga dapat dikurangi. Adapun dengan program rumah sakit gratis berbasis zakat mampu mengurangi kemiskinan mustahik sebesar 10 persen.

Jika setiap orang Islam telah menyadari tentang kewajiban berzakat dan mengetahui berbagai macam manfaat yang akan diperoleh dengan berzakat, maka potensi zakat seharusnya dapat tercapai. Kemudian, yang lebih penting lagi adalah bahwa dana zakat tidak hanya terkumpul secara optimal, namun diharapkan terjadi distribusi yang adil diantara penerima zakat. Sehingga manfaatnya menjadi lebih terasa. 
Dilatarbelakangi oleh hal-hal diatas, maka peneliti melakukan kajian untuk mengetahui faktor-faktor yang memengaruhi kepatuhan dalam membayar zakat. Dalam penelitian ini tidak hanya mencari alasan yang berkaitan dengan aspek keagamaan seseorang yang membayar zakat (muzakki), akan tetapi untuk mengetahui alasan lain yang mendasari seseorang untuk membayar zakat. Selain itu dicari juga alasan yang melatarbelakangi wajib zakat dalam memilih tempat membayar zakat.

\subsection{Tujuan Penelitian}

Penelitian ini bertujuan untuk:

1. Mengidentifikasi faktor-faktor yang memengaruhi tingkat kepatuhan membayar zakat.

2. Mengidentifikasi faktor yang dominan yang memengaruhi kepatuhan membayar zakat, agar dapat menghasilkan kebijakan yang optimal.

\subsection{Ruang Lingkup Penelitian}

Ruang lingkup penelitian ini adalah melakukan analisis faktor-faktor yang memengaruhi tingkat kepatuhan membayar zakat dan menganalisis alasan-alasan seseorang membayar zakat di OPZ dan langsung ke penerima zakat. Penelitian ini dilakukan di wilayah Kabupaten Bogor dengan jumlah responden sebanyak 100 orang.

\section{TINJAUAN PUSTAKA}

\subsection{Definisi Zakat}

Menurut Hafidhuddin (2002), "Ditinjau dari segi bahasa, kata zakat mempunyai beberapa arti, yaitu al-barakatu 'keberkahan', al-namaa 'pertumbuhan dan perkembangan', ath-thaharatu 'kesucian', dan ash-shalahu 'keberesan'. Secara istilah, zakat adalah bagian dari harta yang telah Allah ta'ala wajibkan kepada pemiliknya untuk diserahkan kepada yang berhak menerimanya, dengan persyaratan tertentu."

Zakat merupakan salah satu rukun Islam. Dalam Al-Quran kata zakat disebut secara bersamasama dengan sholat pada 82 tempat (ayat). Dan Allah telah menetapkan kewajibannya baik melalui Kitab-Nya, Sunnah Rasul-Nya, maupun Ijma' dari umat Islam.

Diantara dalil wajibnya zakat adalah firman Allah pada surat At-taubah ayat 103 yang artinya: "Ambillah zakat dari sebagian harta mereka, dengan zakat itu kamu membersihkan" dan mensucikan ${ }^{2}$ mereka dan mendoalah untuk mereka. Sesungguhnya doa kamu itu (menjadi) ketenteraman jiwa bagi mereka. Dan Allah Maha Mendengar lagi Maha Mengetahui." (Q.S. At-Taubah [9]: 103)

Pada fase Mekah, ketika Rasul belum hijrah, tidak ada batasan besaran harta yang wajib untuk dikeluarkan zakatnya, pun tidak ada ketentuan jumlah harta yang harus dizakatkan. Semuanya dikembalikan kepada kesadaran dan kerelaan orang Islam itu sendiri. Baru pada tahun kedua hijrah -menurut keterangan mayoritas/terkenal- ditetapkan besaran dan jumlah harta, serta jenis harta yang harus dikeluarkan zakatnya (Sabiq, 1990).

\subsection{Potensi Zakat di Indonesia}

Kahf (1987) melakukan studi untuk mengestimasi potensi zakat yang ada pada delapan negara Islam, yaitu Mesir, Indonesia, Pakistan, Qatar, Saudi Arabia, Sudan, Syria, dan Turki.

\footnotetext{
${ }^{1}$ Maksudnya: zakat itu membersihkan mereka dari kekikiran dan cinta yang berlebih-lebihan kepada harta benda

${ }^{2}$ Maksudnya: zakat itu menyuburkan sifat-sifat kebaikan dalam hati mereka dan memperkembangkan harta benda mereka.
} 
Kahf melihat estimasi potensi zakat melalui tiga cara, yaitu berdasarkan fikih tradisional, berdasarkan perhitungan dari Qardawi yaitu zakat pendapatan dihitung 2,5 persen, sedangkan keuntungan bersih pada fix aset dihitung 10 persen, dan berdasarkan modifikasi dari versi Qardawi, yaitu zakat dari fix aset dan pendapatan dihitung bersama-sama sebesar 2,5 persen.

Estimasi zakat dari sisi perhitungan fikih tradisional menghasilkan nilai yang lebih kecil daripada estimasi perhitungan dua cara lainnya. Estimasi persentase zakat pada sudut pandang fikih tradisional berkisar antara 0,9 sampai 4,3 persen dari Pendapatan Domestik Bruto (PDB). Sedangkan dari sisi pandang Qardawi, estimasi zakat berkisar antara 1,7 sampai 6,6 persen. Menurut cara perhitungan yang ketiga estimasi zakat berkisar antara 2 sampai 7,5 persen. Selengkapnya dapat dilihat pada tabel berikut.

Tabel 2. Persentase estimasi zakat terhadap PDB di beberapa negara muslim.

\begin{tabular}{|c|c|c|c|}
\hline Negara & $\mathbf{Z}_{\mathbf{1}}$ & $\mathbf{Z}_{\mathbf{2}}$ & $\mathbf{Z}_{\mathbf{3}}$ \\
\hline Mesir & 2 & 3,9 & 4,9 \\
\hline Indonesia & 1 & 1,7 & 2 \\
\hline Pakistan & 1,6 & 3,5 & 4,4 \\
\hline Qatar & 0,9 & 3,7 & 3,2 \\
\hline Saudi Arabia & 1,2 & 3,7 & 3,4 \\
\hline Sudan & 4,3 & 6,6 & 6,2 \\
\hline Siria & 1,5 & 3,1 & 3,1 \\
\hline Turki & 1,9 & 4,9 & 7,5 \\
\hline
\end{tabular}

Keterangan:

$\mathrm{Z}_{1}$ : Perhitungan berdasarkan fikih tradisional

$\mathrm{Z}_{2}$ : Perhitungan berdasarkan Qardawi

$\mathrm{Z}_{3}$ : Perhitungan berdasarkan versi Qardawi yang telah di modifikasi.

Sumber: Kahf, 1987

Dari hasil diatas dapat diketahui bahwa potensi zakat Indonesia berkisar 1 sampai 2 persen dari PDB. Untuk mengetahui potensi zakat di Indonesia secara lebih rinci, Fakultas Ekonomi dan Manajemen (FEM) IPB bekerja sama dengan BAZNAS melakukan penelitian pada tahun 2011. Perhitungan potensi zakat ini dibagi ke dalam tiga bagian, yaitu: (1) Zakat dari sektor industri dan BUMN, (2) Zakat dari rumah tangga, dan (3) Zakat dari tabungan.

Dari sektor industri dan BUMN, total potensi zakat yang dapat diperoleh mencapai Rp 117,29 triliun. Hal ini setara dengan 1,84 persen PDB. Nilai ini diperoleh dari industri pengolahan sebesar Rp 22 triliun, industri penyediaan akomodasi sebesar Rp 88 triliun, dan industri makanan dan minuman sebesar Rp 3,7 triliun. Dari BUMN potensi zakat yang tercapai sebesar Rp 2,4 triliun. Namun, relaisasi zakat pada sektor BUMN baru tercapai Rp 4-5 milyar per tahun. 
Tabel 3. Potensi zakat industri swasta nasional dan BUMN

\begin{tabular}{|l|cr|}
\hline \multicolumn{1}{|c|}{ Industri } & \multicolumn{2}{c|}{ Potensi Zakat } \\
\hline 1) Industri Pengolahan & $\mathrm{Rp}$ & 22,08 triliun \\
\hline 2) Industri Konstruksi & $\mathrm{Rp}$ & 399,35 miliar \\
\hline 3) Jasa Masyarakat & $\mathrm{Rp}$ & $22,12 \mathrm{miliar}$ \\
\hline 4) Pariwisata & $\mathrm{Rp}$ & 66,46 miliar \\
\hline 5) Listrik & $\mathrm{Rp}$ & 0 \\
\hline 6) Air Bersih & $\mathrm{Rp}$ & 54,79 miliar \\
\hline 7) Penyediaan Akomodasi & $\mathrm{Rp}$ & 88,02 triliun \\
\hline 8) Pedagang Besar dan Eceran & $\mathrm{Rp}$ & 2,29 triliun \\
\hline 9) Jasa Kesehatan dan Kegiatan Sosial & $\mathrm{Rp}$ & 86,02 miliar \\
\hline 10) Real Estate & $\mathrm{Rp}$ & 1,73 triliun \\
\hline 11) Pendidikan & $\mathrm{Rp}$ & 135,71 miliar \\
\hline Total & $\mathbf{R p}$ & $\mathbf{1 1 4 , 8 9}$ triliun \\
\hline Potensi Zakat BUMN & $\mathrm{Rp}$ & 2,4 triliun \\
\hline Total Potensi Zakat Industri dan BUMN & $\mathbf{R p}$ & $\mathbf{1 1 7 , 2 9}$ triliun \\
\hline
\end{tabular}

Sumber: BPS, 2006 (diolah)

Potensi zakat rumah tangga pada tahun 2009 dapat mencapai Rp 82,7 triliun (dengan nishab beras) atau setara dengan 1,30 persen dari PDB. Jika pada tahun 2011 PDB mencapai Rp 7 ribu triliun (asumsi makro) maka prediksi potensi zakat rumah tangga mencapai Rp 91 triliun. Wilayah yang berpotensi zakat dibagi kedalam dua bagian, yaitu: (1) Wilayah dengan potensi zakat tertinggi dan (2) Wilayah dengan potensi zakat terendah.

Propinsi yang masuk pada wilayah dengan potensi zakat tertinggi adalah Jawa Barat, Jawa Tengah, dan Jawa Timur. Sedangkan propinsi yang masuk pada wilayah dengan potensi zakat terendah adalah, Papua Barat, Papua, dan Bali. Dari hal ini, dapat disimpulkan bahwa jumlah penduduk muslim pada suatu daerah ikut memengaruhi tingkat potensi zakat di daerah tersebut. Pada wilayah yang berpotensi tinggi, diketahui bahwa mayoritas penduduknya adalah beragama Islam, sedangkan pada wilayah yang potensi zakatnya rendah diketahui mayoritas penduduknya bukan beragama Islam.

Tabel 4. Potensi zakat rumah tangga nasional

\begin{tabular}{|l|l|lr|}
\hline \multirow{2}{*}{ Keterangan } & Nama Wilayah & \multicolumn{2}{|c|}{$\begin{array}{c}\text { Potensi Zakat } \\
\text { (Milyar) }\end{array}$} \\
\hline \multirow{2}{*}{$\begin{array}{l}\text { Wilayah dengan potensi zakat } \\
\text { tertinggi }\end{array}$} & Jawa Barat & $\mathrm{Rp}$ & 17.668 \\
\cline { 2 - 4 } & Jawa Timur & $\mathrm{Rp}$ & 15.494 \\
\cline { 2 - 4 } & Jawa Tengah & $\mathrm{Rp}$ & 13.280 \\
\hline \multirow{2}{*}{$\begin{array}{l}\text { Wilayah dengan potensi zakat } \\
\text { terendah }\end{array}$} & Papua Barat & $\mathrm{Rp}$ & 112 \\
\cline { 2 - 4 } & Papua & $\mathrm{Rp}$ & 117 \\
\cline { 2 - 4 } & Bali & $\mathrm{Rp}$ & 126 \\
\hline Potensi Zakat Rumah Tangga Nasional 2009 & $\mathrm{Rp}$ & 82.700 \\
\hline \multicolumn{2}{|l|}{ Prediksi Potensi Zakat Rumah Tangga Nasional 2011 } & \multicolumn{2}{c}{} \\
\hline
\end{tabular}

Sumber: BPS, 2009 (diolah)

Dari sisi tabungan, potensi zakat dilihat kedalam dua bagian: (1) Tabungan umum dan (2) Tabungan Syariah. Potensi zakat dari sektor tabungan umum memiliki nilai yang lebih besar dari potensi zakat dari sektor tabungan syariah. Pada tabungan umum, potensi zakat yang 
dapat diperoleh mencapai Rp 19,613 triliun. Pada tabungan syariah, potensi zakat yang dapat diperoleh mencapai Rp 895 miliar. Nilai yang berbeda ini salah satunya disebabkan oleh kebanyakan masyarakat Indonesia yang masih menabung di bank umum daripada di bank syariah.

Jika dijumlahkan, estimasi potensi zakat yang dapat dicapai dari sektor industri, rumah tangga, dan tabungan per tahunnya sekitar Rp 217 triliun, hal ini setara dengan 3,4 persen PDB pada tahun 2010.

\subsection{Zakat di Kabupaten Bogor}

Kabupaten Bogor memiliki badan yang bertugas untuk menghimpun dana zakat, infak, dan shodaqoh, kemudian menyalurkan dana tersebut kepada yang berhak guna mengurangi masalah-masalah kemikinan dan ketidakberdayaan. Badan tersebut bernama Badan Amil Zakat (BAZ) Kabupaten Bogor. Pembentukan BAZ Kabupaten Bogor difasilitasi oleh pemerintah dan didukung oleh para tokoh agama dan tokoh masyarakat Kabupaten Bogor, dengan berdasar undang-undang Nomor 38 Tahun 1999.

Visi BAZ Kabupaten Bogor adalah terwujudnya BAZ Kabupaten Bogor yang amanah, kuat, dan menjadi salah satu institusi terdepan dalam melakukan pemberdayaan kaum fakir dan miskin dan ikut mewujudkan masyarakat Kabupaten Bogor yang maju, mandiri dan sejahtera berdasarkan iman dan taqwa.

Untuk mewujudkan visi tersebut, BAZ Kabupaten Bogor memiliki misi-misi sebagai berikut: (1) Mewujudkan akuntabilitas dan transparansi pengelolaan dana zakat, infak, dan shodaqoh (ZIS), (2) Melakukan optimalisasi pengumpulan dana ZIS, (3) Pendistribusian dana ZIS tepat sasaran, (4) Penguatan SDM dikalangan umat yang mampu memiliki kecerdasan intelektual, emosional dan spiritual, (5) Pemulihan dan pemberdayaan ekonomi ummat melalui bantuan modal kerja, pelatihan dalam upaya merubah mustahik menjadi muzaki.

Program kerja yang dimiliki BAZ Kabupaten Bogor terdiri dari beberapa macam, yaitu: (1) Terima kasih guru ngaji, (2) Bina insan mandiri (Pemberdayaan Ekonomi), (3) DIK-OTA (Dana Pendidikan dan Orang Tua Asuh), (4) BIMAS (bina masyarakat sehat), (5) BAKSOWAH (Bantuan sosial dan dakwah), (6) RAGAM (bantuan sarana keagamaan).

Selama tahun 2006-2010 dana zakat yang diterima oleh BAZ Kabupaten Bogor selalu mengalami kenaikan dengan nilai yang cukup besar. Terjadi peningkatan sebesar 1066 persen pada penerimaan zakat tahun 2010 jika dibandingkan dengan penerimaan zakat pada tahun 2006. Hal ini berarti telah terjadi penerimaan zakat yang besarnya lebih dari sepuluh kali lipat dari penerimaan zakat pada tahun 2006. Peningkatan yang paling besar terjadi pada penerimaan zakat mal, rata-rata kenaikannya adalah sebesar 119 persen. Hal ini mungkin dikarenakan adanya instruksi Bupati Bogor nomor 451.5/1/Inst/ Huk/2008 tanggal 22 Mei 2008 tentang zakat profesi bagi pegawai di lingkungan Pemerintah Kabupaten Bogor.

Tabel 5. Tabel penerimaan dana zakat oleh BAZ Kabupaten Bogor

\begin{tabular}{|r|rrr|l|lr|}
\hline \multirow{2}{*}{ No } & \multirow{2}{*}{ Tahun } & \multicolumn{4}{|c|}{ Penerimaan BAZ } & \multirow{2}{*}{ Total Penerimaan } \\
\cline { 3 - 6 } & & \multicolumn{2}{|c|}{ Zakat Mal } & \multicolumn{1}{|}{ Infaq } & & \\
\hline 1 & 2006 & $\mathrm{Rp}$ & 75.300 .750 & $\mathrm{Rp} \mathrm{102.419.575}$ & $\mathrm{Rp}$ & 177.720 .325 \\
\hline 2 & 2007 & $\mathrm{Rp}$ & 169.968 .600 & $\mathrm{Rp} \mathrm{268.192.775}$ & $\mathrm{Rp}$ & 438.161 .375 \\
\hline 3 & 2008 & $\mathrm{Rp}$ & 449.584 .884 & $\mathrm{Rp} \mathrm{225.469.700}$ & $\mathrm{Rp}$ & 675.054 .584 \\
\hline 4 & 2009 & $\mathrm{Rp}$ & 1.153 .607 .928 & $\mathrm{Rp} \mathrm{236.210.542}$ & $\mathrm{Rp}$ & 1.389 .818 .470 \\
\hline 5 & 2010 & $\mathrm{Rp}$ & 1.489 .174 .877 & $\mathrm{Rp} \mathrm{583.929.583}$ & $\mathrm{Rp}$ & 2.073 .104 .460 \\
\hline
\end{tabular}

Sumber: BAZDA Kabupaten Bogor 
Meskipun nilai penerimaan zakat mengalami peningkatan yang signifikan, pihak BAZ masih mengalami beberapa kendala dalam menghimpun dana zakat, diantaranya sebagai berikut: (1) masyarakat di wilayah Kabupaten Bogor masih memiliki tingkat kesadaran yang rendah dalam menunaikan kewajiban berzakat. (2) Kepercayaan dari pihak masyarakat untuk membayar zakat di BAZ Kabupaten Bogor belum maksimal. (3) Masyarakat terbiasa untuk menyalurkan zakat ke tokoh agama setempat atau ke lembaga keagamaan di daerahnya. (4) Zakat mal belum tersosialisasi secara optimal oleh BAZ. (5) Belum ditemukan cara efektif yang dapat menggugah pegawai pemda agar mau menyalurkan zakatnya ke BAZ Kabupaten Bogor (laporan tahunan zakat BAZ Kabupaten Bogor).

\subsection{Penelitian Terdahulu}

Dalam paper yang dipresentasikan oleh Muda, et al. (2006) yang berjudul "Factors Influencing Individual Participation in Zakah Contribution: Exploratory Investigation", disebutkan bahwa seseorang yang membayar zakat tidak hanya dipengaruhi oleh faktor agama, ada faktor-faktor lain yang menyebabkan seseorang mau mengeluarkan zakat, seperti faktor altruism, faktor organisasi zakat, dan faktor kepuasan diri. Pengumpulan data yang dilakukan oleh peneliti ini adalah dengan cara menyebarkan kuesioner kepada 60 orang, namun hanya 53 kuesioner yang layak untuk digunakan dalam penelitian. Dalam kuesioner tersebut terdapat 34 pertanyaan yang harus diisi oleh responden. Hasil dari penelitian tersebut didapatkan berbagai macam faktor yang memengaruhi seseorang untuk membayar zakat, faktor-faktor tersebut memiliki nilai varian sebesar 67,32 persen. Analisis lebih jauh mendapatkan hasil bahwa faktor altruism seseorang memiliki nilai komposit tertinggi yang mengindikasikan bahwa kebanyakan orang membayar zakat karena faktor ini, faktor selanjutnya yang memengaruhi seseorang untuk membayar zakat adalah faktor kepuasan diri, faktor organisasi, dan faktor utilitas. Kesimpulannya adalah bahwa untuk meningkatkan nilai zakat, tidak hanya dilakukan perbaikan kualitas agama seseorang, namun juga perlu diperbaiki kinerja organisasi pengelola zakat.

Berkaitan dengan kinerja lembaga amil zakat, Ahmad dan Wahid (2005) melakukan sebuah penelitian yang berjudul "Persepsi Agihan Zakat dan Kesannya Terhadap Pembayar Zakat Melalui Institusi Formal". Hasil dari kajian ini menyatakan bahwa persepsi masyarakat terhadap distribusi dana zakat yang dilakukan oleh lembaga zakat memengaruhi tingkat kepatuhan wajib zakat secara positif. Artinya, jika suatu lembaga amil zakat melakukan distribusi dana zakat dengan baik, menyalurkan dana zakat kepada orang-orang yang berhak menerimanya, dan tidak melakukan penyelewengan terhadap dana zakat, maka hal ini akan membuat wajib zakat tetap bertahan untuk membayar zakat di tempat tersebut. Selain itu jika suatu organisasi melakukan kampanye/sosialisasi zakat dan meningkatkan kualitas pelayanannya, maka hal ini akan berpengaruh secara nyata dalam memengaruhi seseorang untuk membayar zakat di lembaga tersebut.

Shalihati (2010) mengadakan penelitian tentang persepsi dan sikap wajib zakat yang membayar zakat melalui BAZNAS. Dari enam atribut yang digunakan di multiatribut Fishbein yaitu product, place, people, promotion, process, dan physical evidence, terlihat rata-rata tingkat keyakinan ke enam atribut mengenai BAZNAS, penilaian keyakinan Muzzaki Lembaga lebih tinggi dibandingkan dengan Muzzaki Non-Lembaga. Namun tingkat harapan terhadap ke enam atribut baik Muzzaki Lembaga maupun Muzzaki Non-Lembaga hampir memiliki perbedaan yang tidak terlalu jauh. Dari perhitungan Ao (sikap konsumen) secara keseluruhan diperoleh skor multi atribut Fishbein Muzzaki Lembaga sebesar 97.37, dan Muzzaki Non-Lembaga 90.41. Hal ini menunjukan bahwa secara keseluruhan Muzzaki Lembaga memang lebih menyukai Lembaga BAZNAS untuk menyalukan zakatnya dibandingkan Muzzaki Non-Lembaga. 
Kemudian penelitian yang dilakukan oleh Saad, et al (2009) tentang sikap pengusaha terhadap aturan yang mengharuskan pengusaha membayar zakat melalui organisasi pengelola zakat. Penelitian ini dilakukan pada wilayah Kedah, Malaysia, dan yang menjadi respondennya adalah para pengusaha.

Hasil penelitian ini mendapatkan bahwa para pengusaha memiliki sikap yang berbeda-beda terhadap aturan tersebut, sikap itu terbagi kedalam lima macam, yaitu: (1) Sikap mendorong, (2) Sikap positif, (3) Sikap penolakan total, (4) Sikap Bersyarat, dan (5) Sikap Penolakan bersyarat.

Sikap mendorong merupakan bentuk penerimaan masyarakat secara umum mengenai pembayaran zakat kepada institusi zakat. Dalam komponen ini, pengusaha secara keseluruhan memiliki sikap percaya dan baik dengan peraturan yang telah ditetapkan. Sikap positif menunjukkan pengusaha menerima secara positif terhadap peraturan tersebut.

Sikap penolakan total merupakan pandangan negatif pengusaha terhadap peraturan tersebut, pengusaha cenderung menolak peraturan tersebut. Sikap bersyarat adalah keadaan yang menunjukkan bahwa pengusaha menerima aturan tersebut tetapi mempunyai syarat-syarat tertentu sebelum aturannya dipatuhi. Dua syarat utama yang dimaksud adalah menunggu arahan dan penjelasan dari institusi zakat. Sikap penolakan berprasangka merupakan pandangan pengusaha yang mempunyai prasangka terhadap institusi zakat. Dua bentuk prasangka itu ialah perasaan was-was dan ragu dengan cara institusi zakat melaksanakan urusan zakat.

\section{METODE PENELITIAN}

\subsection{Metode Pengumpulan Data}

Jenis data yang digunakan dalam penelitian ini adalah data primer dan data sekunder. Pengumpulan data dilakukan melalui pemberian kuesioner dan wawancara dengan sebagian masyarakat di Kabupaten Bogor. Poin-poin pertanyaan sudah tercantum dalam lembaran kuesioner. Data sekunder yang digunakan diperoleh dari berbagai sumber, seperti BAZ Kabupaten Bogor, buku, internet, dan dari hasil studi lainnya.

\subsection{Metode Penarikan Sampel}

Teknik pengambilan sampel yang digunakan adalah nonprobability sampling dengan jenis purposive sampling, yaitu teknik pengambilan sampel dengan pertimbangan bahwa responden adalah orang yang diperkirakan sebagai wajib zakat.

Menurut Santoso (2010), jumlah sampel yang dianjurkan pada analisis faktor adalah antara 50-100. Penulis mengambil sampel sebanyak 100 orang, hal ini didasari pada keterbatasan waktu, sumberdaya, dan biaya yang dihadapi oleh penulis.

\subsection{Variabel Penelitian}

Variabel penelitian yang digunakan dalam penelitian ini mengacu kepada penelitian yang dilakukan oleh Muda, et al (2006), yaitu altruisme, tingkat keimanan, utilitas, kepuasaan diri, dan faktor organisasi. 
Tabel 6. Variabel penelitian

\begin{tabular}{|c|c|c|}
\hline No & Faktor & Variabel \\
\hline \multirow[t]{7}{*}{1} & \multirow[t]{7}{*}{ Keimanan } & Sholat fardhu lima kali dalam satu hari \\
\hline & & Sholat fardhu berjamaah di mesjid \\
\hline & & Kewajiban berzakat \\
\hline & & Kemampuan menghitung zakat \\
\hline & & Rutin membaca buku agama \\
\hline & & Rutin ikut pengajian \\
\hline & & Percaya dengan semua balasan \\
\hline \multirow[t]{3}{*}{2} & \multirow[t]{3}{*}{ Penghargaan } & Agar disebut dermawan \\
\hline & & Agar mendapat kemudahan rezeki \\
\hline & & Sambutan dari lingkungan yang baik. \\
\hline \multirow[t]{5}{*}{3} & \multirow[t]{5}{*}{ Altruisme } & Perasaan iba terhadap fakir miskin \\
\hline & & Zakat sebagai upaya bersyukur \\
\hline & & Membersihkan harta \\
\hline & & Kegemaran membantu fakir miskin \\
\hline & & Perasaan bersalah jika tidak membayar zakat \\
\hline \multirow[t]{3}{*}{4} & \multirow[t]{3}{*}{ Kepuasan diri } & Kegemaran meningkatkan kondisi ekonomi fakir miskin \\
\hline & & $\begin{array}{l}\text { Menyadari bahwa ada hak orang lain dalam harta } \\
\text { pribadi }\end{array}$ \\
\hline & & Berperan menjadi contoh yang baik bagi orang lain. \\
\hline \multirow[t]{5}{*}{5} & \multirow[t]{5}{*}{ Organisasi } & Tingkat kecakapan lembaga zakat \\
\hline & & Lembaga zakat yang transparan \\
\hline & & Kenyamanan membayar zakat di lembaga zakat \\
\hline & & $\begin{array}{l}\text { Sosialisasi melalui media massa, elektronik atau } \\
\text { langsung }\end{array}$ \\
\hline & & $\begin{array}{l}\text { Pemotongan gaji melalui institusi tempat seseorang } \\
\text { bekerja. }\end{array}$ \\
\hline
\end{tabular}

\subsection{Metode Analisis Dan Pengolahan Data}

Proses analisis faktor mencoba untuk menemukan hubungan antara sejumlah variabelvariabel yang saling independen satu dengan yang lain, sehingga nantinya dapat dibuat satu atau beberapa kumpulan variabel yang lebih sedikit dari jumlah variabel awal (Santoso, 2010).

Melalui analisis faktor dapat diketahui faktor yang unggul atau yang dominan dari beberapa variabel yang akan dipilih. Analisis faktor juga dapat membedakan variabel prioritas yang diurut berdasarkan hasil analisis tersebut. (Enas, 2011)

Ada beberapa asumsi yang harus terpenuhi dalam analisis faktor, yaitu sebagai berikut:

1. Korelasi atau keterkaitan antar variabel harus kuat.

Hal ini dapat diketahui dari nilai determinannya yang mendekati nol. Nilai determinan dari matriks korelasi yang elemen-elemennya mempunyai matriks identitas akan memiliki nilai determinan sebesar satu. 
2. Indeks perbandingan jarak antara koefisien dengan koefisien korelasi parsialnya secara keseluruhan harus kecil.

Hal ini dapat diidentifikasi dengan nilai Kaiser-Meyer-Olkin (KMO). KMO adalah salah satu indeks perbandingan jarak antara koefisien dengan koefisien korelasi parsialnya secara keseluruhan. Nilai KMO harus $\geq 0,5$ agar analisis faktor dapat dilakukan.

Selain dengan KMO juga digunakan Measure of Sampling Adequacy (MSA). Syarat analisis faktor dapat dilakukan adalah memiliki nilai MSA $\geq 0,5$. Jika ada variabel yang memiliki nilai MSA $<0,5$ maka variabel tersebut harus dikeluarkan terlebih dahulu.

Penelitian ini menggunakan skala likert agar data kualitatif dapat dikuantitatifkan, skala ini dapat digunakan untuk mengukur sikap, pendapat, dan persepsi seseorang atau sekelompok orang tentang fenomena sosial. Jawaban dari variabel instrumen yang menggunakan skala likert terdiri dari lima tingkat, yaitu sangat setuju, setuju, cukup setuju, tidak setuju, sangat tidak setuju.

Tahapan-tahapan yang dilakukan dalam analisis faktor dengan software SPSS versi 17 adalah sebagai berikut:

1. Uji kelayakan data dengan melihat nilai indeks Kaiser Meyer-Olkin (KMO), agar dapat dilihat kelayakan data tersebut untuk penelitian.

2. Melihat jumlah faktor yang terbentuk pada tabel total variance explained.

3. Melihat faktor-faktor apa saja yang masuk ke dalam suatu faktor pada tabel rotated component matrix berdasarkan factor loading terbesar.

\section{HASIL DAN PEMBAHASAN}

Dari hasil penyebaran kuesioner, didapatkan bahwa kebanyakan yang menjadi responden adalah laki-laki yakni sebesar 69 persen, sedangkan responden perempuan sebesar 31 persen. Berdasarkan kategori usia, persentase tertinggi ada pada responden yang berusia 40-49 tahun yaitu sebesar 31 persen, kemudian pada usia 30-39 tahun yaitu sebesar 30 persen.

Pada umumnya, responden bekerja sebagai PNS yaitu sebesar 49 persen, lalu diikuti dengan pekerjaan wiraswasta sebesar 17 persen, lalu sebagai karyawan swasta sebesar 12 persen. Selain itu ada juga responden yang bekerja sebagai pedagang dan ada yang bekerja pada BUMN.

Tingkat pendidikan responden didominasi oleh responden yang berpendidikan terakhir S1 dan SMA. Total persentase untuk kedua tingkat pendidikan tersebut adalah sebesar 77 persen. Sedangkan yang terendah adalah responden yang berpendidikan SD dan SMP, masing-masing bernilai 2 persen.

Rata-rata penghasilan responden berkisar di nilai Rp 2,5 juta sampai Rp 5 juta. Responden yang berpenghasilan dibawah $\mathrm{Rp} 2,5$ juta memiliki tingkat persentase yang sama dengan responden yang berpenghasilan di atas $\mathrm{Rp} 5$ juta yaitu sebesar 23 persen.

\subsection{Faktor-Faktor yang Memengaruhi Kepatuhan Membayar Zakat}

Untuk menentukan faktor-faktor yang memengaruhi kepatuhan membayar zakat, alat analisis yang digunakan adalah analisis faktor. Sebelum melakukan analisis faktor, dilakukan uji variabel terlebih dahulu dengan $K M O$ and Bartlett's test, pengujian ini mengharuskan adanya korelasi yang signifikan antara variabel. 
Tabel 7. KMO

\begin{tabular}{|l|l|l|}
\hline Kaiser-Meyer-Olkin Measure of Sampling Adequacy. & 0,777 \\
\hline \multirow{3}{*}{ Bartlett's Test of Sphericity } & Approx. Chi-Square & $1,243 \mathrm{E} 3$ \\
\cline { 2 - 3 } & Df & 300 \\
\cline { 2 - 3 } & Sig. & 0,000 \\
\hline
\end{tabular}

Berdasarkan tabel 8., nilai KMO memiliki indeks yang tinggi yaitu 0,777 (berkisar antara 0,5 sampai 1,0). Hal ini menunjukkan bahwa analisis faktor layak dilakukan. Setelah itu dilakukan uji korelasi, hal ini dapat dilihat dari nilai Bartlett's Test of Sphericity. Dari tabel, nilai tersebut memiliki nilai sig $0.000(<0.05)$ sehingga kita dapat percaya 100 persen bahwa antarvariabel terdapat korelasi. Langkah selanjutnya adalah reduksi variabel, hasil reduksi ini dapat dilihat pada Tabel 8.

Tabel 8. Total variance explained

\begin{tabular}{|c|c|c|c|c|c|c|c|c|c|}
\hline \multirow{2}{*}{ Component } & \multicolumn{3}{|c|}{ Initial Eigenvalues } & \multicolumn{3}{|c|}{$\begin{array}{c}\text { Extraction Sums of Squared } \\
\text { Loadings }\end{array}$} & \multicolumn{3}{|c|}{$\begin{array}{c}\text { Rotation Sums of Squared } \\
\text { Loadings }\end{array}$} \\
\hline & Total & \begin{tabular}{|c|}
$\%$ of \\
Variance \\
\end{tabular} & Cumulative $\%$ & Total & \begin{tabular}{|c|}
$\%$ of \\
Variance
\end{tabular} & Cumulative \% & Total & \begin{tabular}{|c|}
$\%$ of \\
Variance
\end{tabular} & Cumulative \% \\
\hline 1 & 6.039 & 24.155 & 24.155 & 6.039 & 24.155 & 24.155 & 4.581 & 18.322 & 18.322 \\
\hline 2 & 4.443 & 17.773 & 41.928 & 4.443 & 17.773 & 41.928 & 3.035 & 12.142 & 30.464 \\
\hline 3 & 1.972 & 7.890 & 49.818 & 1.972 & 7.890 & 49.818 & 2.709 & 10.837 & 41.301 \\
\hline 4 & 1.569 & 6.277 & 56.095 & 1.569 & 6.277 & 56.095 & 2.485 & 9.941 & 51.243 \\
\hline 5 & 1.279 & 5.117 & 61.212 & 1.279 & 5.117 & 61.212 & 1.972 & 7.888 & 59.131 \\
\hline 6 & 1.190 & 4.760 & 65.971 & 1.190 & 4.760 & 65.971 & 1.486 & 5.943 & 65.074 \\
\hline 7 & 1.005 & 4.019 & 69.990 & 1.005 & 4.019 & 69.990 & 1.229 & 4.917 & 69.990 \\
\hline 8 & .927 & 3.707 & 73.698 & & & & & & \\
\hline 9 & .770 & 3.080 & 76.778 & & & & & & \\
\hline 10 & .735 & 2.939 & 79.717 & & & & & & \\
\hline 11 & .615 & 2.461 & 82.179 & & & & & & \\
\hline 12 & .537 & 2.149 & 84.328 & & & & & & \\
\hline 13 & .506 & 2.024 & 86.352 & & & & & & \\
\hline 14 & .465 & 1.860 & 88.213 & & & & & & \\
\hline 15 & .464 & 1.856 & 90.069 & & & & & & \\
\hline 16 & .411 & 1.643 & 91.712 & & & & & & \\
\hline 17 & .354 & 1.415 & 93.128 & & & & & & \\
\hline 18 & .325 & 1.299 & 94.427 & & & & & & \\
\hline 19 & .275 & 1.100 & 95.527 & & & & & & \\
\hline 20 & .254 & 1.017 & 96.544 & & & & & & \\
\hline 21 & .234 & .937 & 97.481 & & & & & & \\
\hline 22 & .212 & .850 & 98.330 & & & & & & \\
\hline 23 & .174 & .698 & 99.028 & & & & & & \\
\hline 24 & .145 & .582 & 99.610 & & & & & & \\
\hline 25 & .098 & .390 & 100.000 & & & & & & \\
\hline
\end{tabular}

Sumber: Data primer, 2011 (diolah)

Tabel 8. memperlihatkan 25 variabel yang dimasukkan ke dalam analisis faktor. Kolom initial eigenvalues menunjukkan kepentingan relatif masing-masing faktor dalam menghitung ke-25 variabel yang dianalisis. Component yang memiliki nilai eigen yang kurang dari 1 (yaitu component 8-25) tidak digunakan dalam menghitung faktor yang terbentuk, sehingga faktor yang digunakan hanya sampai pada component 7 .

Setelah mereduksi ke-25 variabel tersebut, kemudian dilakukan pengelompokan variabel ke dalam tujuh fakor hasil reduksi. Alat yang digunakan untuk melakukan pengelompokan adalah rotated component matrix.

Rotated component matrix memaksimalkan nilai loading dari setiap variabel yang memiliki korelasi dengan faktor tertentu dan meminimalkan nilai loading setiap variabel yang tidak memiliki korelasi/berkorelasi lemah dengan faktor tertentu. 
Pada rotated component matrix berikut digunakan pilihan blank sebesar 0,5. Hal ini membuat software SPSS tidak akan menampilkan korelasi yang berada pada level 0,5 atau yang ada di bawahnya, hal ini akan mempermudah pengelompokkan variabel.

Tabel 9. Rotated component matrix

\begin{tabular}{|l|l|l|l|l|l|l|l|}
\hline \multicolumn{1}{|c|}{ Variabel } & \multicolumn{5}{c|}{ Component } \\
\cline { 2 - 7 } & $\mathbf{1}$ & $\mathbf{2}$ & $\mathbf{3}$ & $\mathbf{4}$ & $\mathbf{5}$ & $\mathbf{6}$ & $\mathbf{7}$ \\
\hline $\begin{array}{l}\text { Anda selalu shalat fardhu 5 } \\
\text { kali dalam satu hari }\end{array}$ & & 0,71 & & & & & \\
\hline $\begin{array}{l}\text { Shalat fardhu berjamaah 3 } \\
\text { kali sehari di masjid }\end{array}$ & & & & 0,67 & & & \\
\hline $\begin{array}{l}\text { Menurut Anda zakat itu } \\
\text { wajib }\end{array}$ & & 0,77 & & & & & \\
\hline $\begin{array}{l}\text { Anda mampu menghitung } \\
\text { zakatnya sendiri }\end{array}$ & & & & & & & \\
\hline $\begin{array}{l}\text { Anda rutin membaca buku- } \\
\text { buku agama }\end{array}$ & & & & 0,81 & & & \\
\hline $\begin{array}{l}\text { Anda rutin hadir di majelis } \\
\text { ilmu }\end{array}$ & & & & 0,79 & & & \\
\hline $\begin{array}{l}\text { Anda percaya dengan semua } \\
\text { balasan atas perbuatan Anda. }\end{array}$ & & 0,65 & & & & & \\
\hline $\begin{array}{l}\text { Anda mendapatkan } \\
\text { kemudahan rezeki setelah } \\
\text { membayar zakat }\end{array}$ & & 0,51 & & & & 0,56 & \\
\hline $\begin{array}{l}\text { Lingkungan sekitar Anda } \\
\text { menyambut baik saat anda } \\
\text { berzakat }\end{array}$ & & & & & & 0,89 & \\
\hline $\begin{array}{l}\text { Anda senang disebut } \\
\text { dermawan setelah berzakat }\end{array}$ & & & & & & & \\
\hline $\begin{array}{l}\text { Anda merasa iba ketika } \\
\text { melihat fakir/miskin }\end{array}$ & & & & & & & \\
\hline $\begin{array}{l}\text { Dengan berzakat atau infak } \\
\text { berarti Anda telah berupaya } \\
\text { untuk bersyukur kepada } \\
\text { Allah }\end{array}$ & & 0,67 & & & & & \\
\hline
\end{tabular}


Tabel 9. Rotated component matrix (lanjutan)

\begin{tabular}{|l|c|c|c|c|c|c|c|}
\hline \multicolumn{1}{|c|}{ Variabel } & \multicolumn{5}{c|}{ Component } \\
\cline { 2 - 8 } & $\mathbf{1}$ & $\mathbf{2}$ & $\mathbf{3}$ & $\mathbf{4}$ & $\mathbf{5}$ & $\mathbf{6}$ & $\mathbf{7}$ \\
\hline $\begin{array}{l}\text { Anda merasa harta Anda } \\
\text { bersih setelah berzakat dan } \\
\text { berinfak }\end{array}$ & & & & & 0,71 & & \\
\hline $\begin{array}{l}\text { Anda senang membantu } \\
\text { fakir/ miskin }\end{array}$ & & & .750 & & & & \\
\hline $\begin{array}{l}\text { Anda merasa bersalah saat } \\
\text { tidak membayar zakat atau } \\
\text { infak }\end{array}$ & & & .853 & & & & \\
\hline $\begin{array}{l}\text { Anda senang dapat } \\
\text { meningkatkan kondisi } \\
\text { ekonomi fakir/miskin }\end{array}$ & 0,89 & & .579 & & & & \\
\hline $\begin{array}{l}\text { Badan amil zakat bekerja } \\
\text { secara profesional }\end{array}$ & & & & & & \\
\hline $\begin{array}{l}\text { Badan amil zakat transparan } \\
\text { dalam hal laporan keuangan }\end{array}$ & 0,77 & & & & & & \\
\hline $\begin{array}{l}\text { Anda merasa nyaman dengan } \\
\text { membayar zakat di badan } \\
\text { amil zakat }\end{array}$ & 0,85 & & & & & & \\
\hline $\begin{array}{l}\text { Layanan di badan amil zakat } \\
\text { memuaskan }\end{array}$ & 0,89 & & & & & & \\
\hline $\begin{array}{l}\text { Badan amil zakat melakukan } \\
\text { sosialisasi melalui media } \\
\text { massa, media elektronik }\end{array}$ & 0,76 & & & & & & \\
\hline $\begin{array}{l}\text { Badan amil zakat melakukan } \\
\text { sosialisasi langsung kepada } \\
\text { masyarakat }\end{array}$ & 0,83 & & & & & & \\
\hline $\begin{array}{l}\text { Bagaimana dengan } \\
\text { pemotongan gaji secara } \\
\text { langsung untuk zakat dari } \\
\text { institusi tempat Anda bekerja }\end{array}$ & & & & & & & \\
\hline
\end{tabular}

Keterangan:

Component $1=$ Kecakapan Organisasi Pengelola Zakat (OPZ)

Component 2 = Keimanan

Component $3=$ Tingkat kepedulian sosial

Component $4=$ Tingkat pemahaman agama

Component $5=$ Kepuasan diri

Component $6=$ Mengharapkan balasan

Component $7=$ Pujian

Sumber: Data primer, 2011 (diolah)

Tabel 9. menerangkan korelasi yang terjadi antara variabel-variabel dengan faktor-faktor yang terbentuk. Penjelasan Tabel 9. dapat dilihat pada uraian berikut.

\subsection{Faktor 1: Kecakapan Organisasi Pengelola Zakat}

Faktor pertama yang terbentuk dari hasil reduksi variabel adalah faktor kecakapan organisasi pengelola zakat. Faktor ini menerangkan keragaman data sebesar 24,155 persen. Tabel 10. memperlihatkan berbagai macam variabel yang termasuk ke dalam faktor kecakapan lembaga amil zakat. 
Dari hasil Tabel 10., variabel yang nilai rata-ratanya paling tinggi adalah variabel OPZ bekerja secara profesional yaitu sebesar 3,87. Hal ini mengindikasikan keprofesionalan OPZ dapat membuat wajib zakat patuh untuk membayar zakat di lembaga tersebut, oleh karena itu, OPZ dapat lebih meningkatkan mutu pelayanannya seperti dalam hal transparansi, sosialisasi, dan administrasi, karena hal ini akan berpengaruh besar terhadap preferensi responden dalam membayar zakat di lembaga tersebut.

Tabel 10. Faktor kecakapan organisasi pengelola zakat

\begin{tabular}{|l|l|l|}
\hline Variabel & Loading & Nilai Rata-rata \\
\hline Layanan di OPZ memuaskan & 0,89 & 3,70 \\
\hline OPZ bekerja secara profesional & 0,89 & 3,87 \\
\hline $\begin{array}{l}\text { Anda merasa nyaman dengan } \\
\text { membayar zakat di OPZ }\end{array}$ & 0,85 & 3,73 \\
\hline $\begin{array}{l}\text { OPZ melakukan sosialisasi } \\
\text { langsung kepada masyarakat }\end{array}$ & 0,83 & 3,45 \\
\hline $\begin{array}{l}\text { OPZ transparan dalam hal } \\
\text { laporan keuangan }\end{array}$ & 0,77 & 3,43 \\
\hline $\begin{array}{l}\text { OPZ melakukan sosialisasi } \\
\text { melalui media massa, media } \\
\text { elektronik }\end{array}$ & 0,76 & 3,27 \\
\hline Total rata-rata & \multicolumn{2}{|c|}{31,44} \\
\hline Nilai komposit & & \\
\hline
\end{tabular}

Sumber: Data primer, 2011 (diolah)

\subsection{Faktor 2: Keimanan}

Faktor berikutnya yang memengaruhi seseorang membayar zakat adalah faktor keimanan. Seorang yang beriman tentunya memiliki keyakinan bahwa ia harus mengeluarkan zakat, ia sudah menyadari kedudukan zakat dalam agamanya. Seseorang yang memiliki tingkat keimanan yang baik akan lebih mudah untuk diajak mengeluarkan zakat daripada mereka yang memiliki tingkat keimanan yang rendah.

Pada faktor ini, terdaapat beberapa variabel yang saling berkaitan, variabel-variabel tersebut adalah variabel menurut anda zakat itu wajib, variabel anda sholat fardhu 5 kali sehari, variabel dengan berzakat atau infak berarti anda telah berupaya untuk bersyukur kepada Allah, variabel anda menyadari bahwa ada hak orang lain dalam harta anda, dan variabel anda percaya dengan semua balasan atas perbuatan anda. Faktor ini menerangkan keragaman data sebesar 17,773 persen. Nilai rata-rata tertinggi pada faktor ini terdapat pada variabel anda selalu sholat fardhu 5 kali dalam satu hari, hal ini menandakan ada hubungan yang erat antara ibadah sholat dengan ibadah zakat. 
Tabel 11. Faktor keimanan

\begin{tabular}{|l|l|l|}
\hline Variabel & Loading & Nilai rata-rata \\
\hline Menurut Anda zakat itu wajib & 0,77 & 4,85 \\
\hline $\begin{array}{l}\text { Anda selalu shalat fardhu 5 kali } \\
\text { dalam satu hari }\end{array}$ & 0,71 & 4,88 \\
\hline $\begin{array}{l}\text { Dengan berzakat atau infak berarti } \\
\text { Anda telah berupaya untuk } \\
\text { bersyukur kepada Allah }\end{array}$ & 0,67 & 4,74 \\
\hline $\begin{array}{l}\text { Anda menyadari bahwa ada hak } \\
\text { orang lain dalam harta Anda }\end{array}$ & 0,66 & 4,72 \\
\hline $\begin{array}{l}\text { Anda percaya dengan semua } \\
\text { balasan atas perbuatan Anda }\end{array}$ & 0,65 & 4,69 \\
\hline Total rata-rata & & 23,88 \\
\hline Nilai komposit & \multicolumn{2}{|l|}{4,78} \\
\hline
\end{tabular}

Sumber: Data primer, 2011 (diolah)

\subsection{Faktor 3: Tingkat Kepedulian Sosial}

Variabel yang masuk ke dalam faktor ini berkaitan dengan tingkat kepedulian sosial yang dimiliki oleh masyarakat. Seseorang mau mengeluarkan zakat karena merasa peduli terhadap keadaan masyarakat di sekitar mereka. Kemudian ada juga diantara mereka yang termotivasi untuk mengeluarkan uang dalam bentuk lain seperti infak atau sodaqoh.

Pada faktor ini, variabel yang terkumpul adalah variabel seseorang memiliki perasaan bersalah jika tidak membayar zakat, variabel senang membantu fakir dan miskin, dan variabel senang meningkatkan kondisi ekonomi fakir dan miskin. Faktor ini menerangkan keragaman data sebesar 7,89 persen. Pada faktor ini, variabel yang memiliki nilai rata-rata tertinggi adalah variabel anda senang membantu fakir dan miskin dengan nilai rata-rata 4,57. Dari hal ini dapat diketahui bahwa pada umumnya responden mengeluarkan zakatnya pada golongan fakir dan miskin. Tabel berikut memperlihatkan faktor tingkat kepedulian sosial dan variabel yang terdapat didalamnya.

Tabel 12. Faktor tingkat kepedulian sosial

\begin{tabular}{|l|l|l|}
\hline Variabel & Loading & Nilai rata-rata \\
\hline $\begin{array}{l}\text { Anda merasa bersalah saat tidak } \\
\text { membayar zakat atau infak }\end{array}$ & 0,85 & 4,48 \\
\hline $\begin{array}{l}\text { Anda senang membantu fakir dan } \\
\text { miskin }\end{array}$ & 0,75 & 4,57 \\
\hline $\begin{array}{l}\text { Anda senang dapat meningkatkan } \\
\text { kondisi ekonomi fakir/miskin }\end{array}$ & 0,58 & 4,39 \\
\hline Total rata-rata & & 13,44 \\
\hline Nilai komposit & & 4,48 \\
\hline
\end{tabular}

Sumber: Data primer, 2011 (diolah)

\subsection{Faktor 4: Tingkat Pemahaman Agama}

Faktor tingkat pemahaman agama mampu menerangkan keragaman data sebesar 6,277 persen. Semakin baik pemahaman agama seseorang seharusnya membuat ia semakin termotivasi untuk menunaikan zakat. Karena ia sudah mengerti bahwa membayar zakat adalah sebuah kewajiban, ia mengetahui balasan-balasan kebaikan yang akan dia dapatkan jika membayar zakat, dan mengetahui hukuman-hukuman bagi mereka yang tidak mau membayar zakat padahal mereka mampu. 
Responden yang termasuk ke dalam faktor ini adalah responden yang rutin membaca buku agama, rutin hadir di majelis ilmu, dan sholat fardhu berjamaah di mesjid minimal 3 kali sehari. Seseorang yang rutin membaca buku-buku agama maka hal ini akan menambah pengetahuan mereka tentang agamanya, yang kemudian menciptakan kesadaran pada dirinya untuk melakukan berbagai macam kebaikan termasuk membayar zakat.

Tabel 13. Faktor tingkat pemahaman agama

\begin{tabular}{|l|l|l|}
\hline Variabel & Loading & Nilai rata-rata \\
\hline $\begin{array}{l}\text { Anda rutin membaca buku-buku } \\
\text { agama }\end{array}$ & 0,81 & 3,88 \\
\hline Anda rutin hadir di majelis ilmu & 0,79 & 3,83 \\
\hline $\begin{array}{l}\text { Shalat fardhu berjamaah min. } 3 \\
\text { kali sehari di masjid }\end{array}$ & 0,67 & 4,03 \\
\hline Total rata-rata & & 11,74 \\
\hline Nilai komposit & & 3,91 \\
\hline
\end{tabular}

Sumber: Data primer, 2011 (diolah)

\subsection{Faktor 5: Kepuasaan Diri}

Variabel-variabel yang masuk ke dalam faktor ini dinamakan sebagai faktor kepuasan diri. Faktor ini menerangkan keragaman data sebesar 5,117 persen. Orang-orang yang masuk ke dalam faktor ini adalah orang-orang yang percaya bahwa mereka dapat memberi contoh yang baik bagi orang lain dengan membayar zakat, mereka termotivasi untuk membayar zakat agar perbuatannya ditiru orang lain, sehingga mereka berharap mendapat ganjaran dari orangorang yang mengikuti kebaikan yang telah mereka contohkan.

Kemudian responden yang termasuk dalam faktor ini adalah responden yang merasa iba jika melihat orang-orang fakir dan miskin. Dengan membayar zakat/infaq/shodaqoh kepada orang fakir dan miskin, maka hal ini menimbulkan harapan agar harta mereka menjadi lebih bersih.

Tabel 14. Faktor kepuasan diri

\begin{tabular}{|l|l|l|}
\hline Variabel & Loading & Nilai rata-rata \\
\hline $\begin{array}{l}\text { Anda percaya dengan berzakat, } \\
\text { Anda menjadi contoh yang baik } \\
\text { bagi orang lain }\end{array}$ & 0,80 & 4,06 \\
\hline $\begin{array}{l}\text { Anda merasa harta Anda bersih } \\
\text { setelah berzakat dan berinfak }\end{array}$ & 0,71 & 4,32 \\
\hline $\begin{array}{l}\text { Anda merasa iba ketika melihat } \\
\text { fakir/miskin }\end{array}$ & 0,65 & 4,37 \\
\hline Total rata-rata & & 12,75 \\
\hline Nilai komposit & \multicolumn{2}{|c|}{4,25} \\
\hline
\end{tabular}

\subsection{Faktor 6: Mengharapkan Balasan}

Faktor selanjutnya adalah faktor mengharapkan balasan, faktor ini menerangkan karakteristik responden yang mau membayar zakat karena mengharapkan sesuatu setelah mereka membayar zakat, seperti lingkungan yang menyambut baik saat mereka berzakat dan harapan mendapatkan kemudahan rezeki setelah membayar zakat. Faktor ini menerangkan keragaman data sebesar 4,76 persen. Varians kumulatif sampai faktor ini mencapai 65,971 persen. 
Tabel 15. Faktor mengharapkan balasan

\begin{tabular}{|l|l|l|}
\hline Variabel & Loading & Nilai rata-rata \\
\hline $\begin{array}{l}\text { Lingkungan sekitar Anda } \\
\text { menyambut baik saat anda } \\
\text { berzakat }\end{array}$ & 0,89 & 4,23 \\
\hline $\begin{array}{l}\text { Anda mendapatkan kemudahan } \\
\text { rezeki setelah membayar zakat }\end{array}$ & 0,56 & 4,65 \\
\hline Total rata-rata & & 8,88 \\
\hline Nilai komposit & & 4,44 \\
\hline
\end{tabular}

Sumber: Data primer, 2011 (diolah)

\subsection{Faktor 7: Pujian}

Pada faktor ini yang mendorong seseorang untuk membayar zakat adalah karena mereka mengharapkan agar disebut dermawan setelah mereka membayar zakat. Jika dilihat dari nilai rata-rata variabelnya, variabel ini adalah faktor yang pengaruhnya paling kecil.

Tabel 16. Faktor pujian

\begin{tabular}{|l|l|l|}
\hline Variabel & Loading & Nilai rata-rata \\
\hline $\begin{array}{l}\text { Anda senang disebut dermawan } \\
\text { setelah berzakat }\end{array}$ & 0,81 & 1,79 \\
\hline Total rata-rata & \multicolumn{2}{|c|}{1,79} \\
\hline Nilai komposit & & 1,79 \\
\hline
\end{tabular}

Sumber: Data primer, 2011 (diolah)

Setelah mengetahui faktor-faktor yang memengaruhi seseorang membayar zakat melalui rotated component matrix, langkah selanjutnya adalah mengurutkan ketujuh variabel tersebut berdasarkan faktor yang paling kuat dalam memengaruhi tingkat kepatuhan membayar zakat. Cara mengurutkannya adalah dengan menggunakan nilai komposit. Nilai komposit ini didapatkan dengan membagi nilai total rata-rata dengan jumlah variabel yang terdapat pada masing-masing faktor. Hasilnya dapat dilihat dari tabel berikut.

Tabel 17. Urutan faktor-faktor

\begin{tabular}{|l|l|l|l|}
\hline Urutan & Faktor-faktor & Total Rata-rata & Nilai Komposit \\
\hline 1 & Faktor Keimanan & 23,88 & 4,78 \\
\hline 2 & Faktor Sosial & 13,44 & 4,48 \\
\hline 3 & Faktor Balasan & 8,88 & 4,44 \\
\hline 4 & Faktor Kepuasan diri & 12,75 & 4,25 \\
\hline 5 & $\begin{array}{l}\text { Faktor Pemahaman } \\
\text { Agama }\end{array}$ & 11,74 & 3,91 \\
\hline 6 & Faktor OPZ & 21,44 & 3,57 \\
\hline 7 & Faktor Pujian & 1,79 & 1,79 \\
\hline
\end{tabular}

Sumber: Data primer, 2011 (diolah)

Faktor keimanan menempati urutan pertama dalam memengaruhi seseorang untuk membayar zakat, nilai komposit faktor ini adalah yang paling besar diantara keenam faktor lainnya, yaitu sebesar 4,78. Hal ini menunjukkan bahwa alasan terkuat seseorang mau membayar zakat adalah karena didorong oleh keimanannya, ia menyadari pentingnya berzakat bagi kehidupan dunia dan akhiratnya, ia juga menyadari bahwa perbuatan baiknya (seperti membayar zakat) pasti akan diberi balasan oleh Allah ta'ala. 
Faktor-faktor lainnya yang memengaruhi kepatuhan membayar zakat adalah faktor sosial, faktor balasan, faktor kepuasan diri, faktor pemahaman agama, dan faktor organisasi. Faktor pujian tidak termasuk kedalam faktor yang memengaruhi kepatuhan membayar zakat, karena faktor ini memiliki nilai komposit yang rendah. Seseorang yang membayar zakat menyadari bahwa tujuan mereka membayar zakat adalah untuk mencari ridho Allah bukan untuk mencari pujian dari manusia, atau agar disebut sebagai orang yang dermawan.

Dari hasil penelitian ini, diketahui sejumlah faktor yang membuat seseorang mau untuk membayar zakat, faktor-faktor tersebut adalah faktor keagamaan seperti iman, pemahaman agama, dan balasan, lalu ada juga faktor-faktor lainnya seperti kepedulian sosial, kepuasan diri, dan organisasi. Hal ini sekaligus memberikan arahan bahwa untuk meningkatkan penerimaan zakat, tidak hanya menekankan aspek keagamaan, tetapi ikut memerhatikan aspek sosial, kepuasan diri, dan organisasi. Hasil penelitian ini hampir serupa dengan penelitian sebelumnya yaitu penelitian yang dilakukan oleh Muda, et al. (2006).

\subsection{Alasan Individu Membayar Zakat di Lembaga Zakat atau Langsung ke Mustahiq}

Tabel 18. menggambarkan alasan seseorang dalam memilih tempat membayar zakat dan pandangan mereka terhadap lembaga zakat:

Tabel 18. Alasan seseorang membayar zakat di organisasi dan mustahiq

\begin{tabular}{|l|l|l|l|}
\hline \multirow{2}{*}{ No } & \multirow{2}{*}{ Variabel } & \multicolumn{2}{|c|}{ Tempat Zakat (\%) } \\
\cline { 3 - 4 } & & OPZ & Mustahiq \\
\hline 1 & Akses & $50 \%$ & $37 \%$ \\
\hline 2 & Ketersediaan Informasi & $48 \%$ & $48 \%$ \\
\hline 3 & Kenyamanan & $50 \%$ & $52 \%$ \\
\hline 4 & Kemudahan & $77 \%$ & $71 \%$ \\
\hline 5 & Lingkungan & $56 \%$ & $54 \%$ \\
\hline 6 & Kepuasan & $46 \%$ & $67 \%$ \\
\hline 7 & Fatwa Kyai Setempat & $21 \%$ & $23 \%$ \\
\hline
\end{tabular}

Sumber: Data primer, 2011 (diolah)

Dari 100 responden yang diberikan kuesioner, tercatat yang membayar zakat di lembaga zakat ada sebanyak 48 responden, sedangkan yang membayar langsung ke penerima zakat ada sebanyak 52 orang. Variabel yang memiliki persentase tertinggi pada kolom OPZ adalah variabel kemudahan. Sebanyak 77 persen responden memilih variabel ini sebagai alasan mereka membayar zakat di OPZ.

Sedangkan alasan wajib zakat membayar zakat langsung ke penerima zakat adalah faktor kepuasan, responden yang membayar zakat langsung ke penerima zakat merasa lebih puas jika dibandingkan dengan responden yang membayar zakat di lembaga zakat, hal ini dilihat dari nilai persentase kepuasan yang lebih besar pada kolom mustahiq (67 persen) daripada kolom lembaga zakat (46 persen).

Persentase alasan yang terendah untuk kedua kolom (OPZ dan mustahiq) ditunjukkan oleh variabel fatwa kyai setempat. Nilai variabel ini pada kolom organisasi adalah sebesar 21 persen, sedangkan pada kolom mustahiq adalah sebesar 23 persen. Hal ini menunjukkan variabel ini tidak memiliki pengaruh yang kuat dalam menentukan preferensi seseorang dalam memilih tempat membayar zakat. 
Tabel 19. Persepsi wajib zakat terhadap transparansi dan profesionalitas OPZ

\begin{tabular}{|l|l|l|l|}
\hline \multirow{2}{*}{ No } & \multirow{2}{*}{ Variabel } & \multicolumn{2}{|c|}{ Jenis Wajib Zakat } \\
\cline { 3 - 4 } & & Muzakki OPZ & Muzakki Non-OPZ \\
\hline 1 & Transparansi OPZ & $63 \%$ & $23 \%$ \\
\hline 2 & Profesionalitas OPZ & $56 \%$ & $15 \%$ \\
\hline
\end{tabular}

Sumber: Data primer, 2011 (diolah)

Tabel diatas menggambarkan persepsi wajib zakat terhadap transparansi dan profesionalitas OPZ. Wajib zakat yang menjadi responden terbagi menjadi dua, yaitu wajib zakat yang membayar zakat ke OPZ (Muzakki OPZ) dan wajib zakat yang membayar zakat langsung ke penerima zakat (Muzakki Non-OPZ).

Dari tabel 19. dapat diketahui bahwa terdapat perbedaan persepsi yang besar antara kedua wajib zakat tersebut terhadap OPZ. Pada kolom muzakki OPZ, kebanyakan mereka menilai bahwa OPZ sudah bekerja secara transparan dan profesional, hal ini diketahui dari nilai persentase yang lebih dari 50 persen untuk kedua variabel tersebut. Sedangkan pada kolom muzakki non-OPZ, hanya sedikit dari mereka yang menilai OPZ telah bekerja secara transparan dan profesional. Hal ini ditandai dengan kecilnya nilai persentase transparansi dan profesionalitas OPZ pada kolom tersebut (yaitu 23\% dan 15\%).

Hasil tabel diatas menunjukkan bahwa kinerja OPZ ikut memengaruhi wajib zakat dalam memilih tempat membayar zakat. Semakin baik kinerja OPZ maka akan semakin banyak wajib zakat yang membayar zakat melalui OPZ.

\section{KESIMPULAN}

\subsection{Kesimpulan}

1. Faktor-faktor yang dominan memengaruhi kepatuhan membayar zakat adalah semua faktor tersebut kecuali faktor pujian.

2. Diantara sebab wajib zakat memilih membayar zakat di OPZ adalah karena OPZ bersifat transparan, profesional, memberi kemudahan dalam berzakat, dan pelayanannya memuaskan. Hal ini dilihat dari penilaian yang tinggi dari orang-orang yang membayar zakat di OPZ terhadap alasan-alasan tersebut

3. Individu yang membayar langsung ke penerima zakat memiliki penilaian yang kurang baik terhadap lembaga zakat, hanya 23 persen yang menilai lembaga zakat bersifat transparan, dan hanya 15 persen yang menilai lembaga zakat profesional. Selain itu, mereka mendapatkan kepuasan yang lebih tinggi dibandingkan dengan membayar zakat di OPZ.

4. Diantara hal-hal yang memengaruhi responden dalam memilih tempat membayar zakat adalah adanya kemudahan dari OPZ, baiknya kinerja OPZ yang dicerminkan oleh transparansi dan profesionalitas, dan sosialisasi dari OPZ.

\section{DAFTAR PUSTAKA}

Ahmad, S. H. Wahid, dan A. Mohamad. 2005. Penswastaan Zakat dan Kesannya Terhadap Pembayaran Secara Formal di Malaysia. Kumpulan Kajian Ekonomi \& Kewangan Islam Pusat Pengajian Ekonomi, UKM.

Ahmed, H. 2004. Zakah, Macroeconomic Policies, and Poverty Alleviation: Lessons from Simulations on Bangladesh. Journal of Islamic Economics, Banking and Finance, 81105. 
Aziz, A. B. A. 2009. Kitab Zakat. Ummu Abdillah [penerjemah]. [e-book] Maktabah Raudhah al-Muhibbin. http://www.raudhatulmuhibbin.org/2009/08/z-k-t.html. [31 Mar 2010].

Badan Amil Zakat Kabupaten Bogor. 2006. "Laporan Tahunan Penerimaan dan Pemanfaatan Dana Zakat, Infaq, dan Shadaqah Tahun 2006".

2007. "Laporan Tahunan Penerimaan dan Pemanfaatan Dana Zakat, Infaq, dan Shadaqah Tahun 2007”.

2008. "Laporan Tahunan Penerimaan dan Pemanfaatan Dana Zakat, Infaq, dan Shadaqah Tahun 2008".

. 2009. "Laporan Tahunan Penerimaan dan Pemanfaatan Dana Zakat, Infaq, dan Shadaqah Tahun 2009".

. 2010. "Laporan Tahunan Penerimaan dan Pemanfaatan Dana Zakat, Infaq, dan Shadaqah Tahun 2010".

Enas, A. Rusyana, dan Riduwan. 2011. Cara Mudah Belajar SPSS 17.0 dan Aplikasi Statistik Penelitian. Alfabeta, Bandung.

Firdaus, M., dan I. S. Beik. 26 Mei 2011. "Potensi Zakat Rumah Tangga Nasional". Republika: 23.

Hafidhuddin, D. 2002. Zakat Dalam Perekonomian Modern. Gema Insani, Jakarta.

Ibrahim, P. 2008. Pembangunan Ekonomi Melalui Agihan Zakat: Tinjauan Empirikal. Jurnal Syariah, 16: 223-244.

Juanda, B., dan A. Hardjanto. 26 Mei 2011. "Potensi Zakat Perusahaan”. Republika: 24.

Kahf, M. 1987. "The Principle of Socio-Economic Justice in The Contemporary Fiqh of Zakah".

Miftah, A. A. 2008. "Pembaharuan Zakat untuk Pengentasan Kemiskinan di Indonesia". Innovatio, 7: 423-439.

Muda, M., A. Marzuki, dan A. Shaharudin. 2006. Factors Influencing Individual Participation In Zakat Contribution: Exploratory Investigation. Kertas kerja pada Seminar for Islamic Banking and Finance 2006, Agustus 2006, Kuala Lumpur.

Saad, R. A., K. M. Idris, dan Z. Bidin. 2009. Peraturan Pembayaran Zakat Kepada Institusi Zakat: Sikap Peniaga dan Kesannya Terhadap Gelagat Pembayaran Zakat Perniagaan. Jurnal Syariah, 17: 607-630.

Sabiq, S. 1990. Fikih Sunnah. Mahyudin Syaf [penerjemah]. PT. Al-Ma'arif, Bandung.

Santoso, S. 2010. Statistik Multivariat. Elex Media Komputindo, Jakarta.

Shalihati, F. 2010. Analisis Persepsi Dan Sikap Muzzaki Terhadap Badan Amil Zakat Nasional Di Kota Jakarta [tesis]. Bogor: Manajemen dan Bisnis, Institut Pertanian Bogor. 
Lampiran 1. Output analisis faktor

KMO and Bartlett's Test

\begin{tabular}{|c|c|c|}
\hline \multicolumn{2}{|c|}{$\begin{array}{l}\text { Kaiser-Meyer-Olkin Measure of Sampling } \\
\text { Adequacy. }\end{array}$} & .777 \\
\hline Bartlett's Test of & Approx. Chi-Square & 1243.111 \\
\hline Sphericity & Df & 300 \\
\hline & Sig. & $6.734 \mathrm{E}-115$ \\
\hline
\end{tabular}

\section{Communalities}

\begin{tabular}{|l|r|r|}
\hline & Initial & Extraction \\
\hline $\begin{array}{l}\text { Anda selalu shalat fardhu 5 kali dalam } \\
\text { satu hari }\end{array}$ & 1.000 & .723 \\
$\begin{array}{l}\text { Shalat fardhu berjamaah 3 kali sehari di } \\
\text { masjid }\end{array}$ & 1.000 & .616 \\
$\begin{array}{l}\text { Menurut Anda zakat itu wajib } \\
\text { Anda mampu menghitung zakatnya } \\
\text { sendiri }\end{array}$ & 1.000 & .691 \\
$\begin{array}{l}\text { Anda rutin membaca buku-buku agama } \\
\text { Anda rutin hadir di majelis ilmu }\end{array}$ & 1.000 & .579 \\
$\begin{array}{l}\text { Anda percaya dengan semua balasan } \\
\text { atas perbuatan Anda. }\end{array}$ & 1.000 & .754 \\
$\begin{array}{l}\text { Anda mendapatkan kemudahan rezeki } \\
\text { setelah membayar zakat }\end{array}$ & 1.000 & .718 \\
$\begin{array}{l}\text { Lingkungan sekitar Anda menyambut } \\
\text { baik saat anda berzakat }\end{array}$ & 1.000 & .675 \\
$\begin{array}{l}\text { Anda senang disebut dermawan setelah } \\
\text { berzakat }\end{array}$ & 1.000 & .691 \\
$\begin{array}{l}\text { Anda merasa iba ketika melihat } \\
\text { fakir/miskin }\end{array}$ & 1.000 & .751 \\
$\begin{array}{l}\text { Dengan berzakat atau infak berarti } \\
\text { Anda telah berupaya untuk bersyukur } \\
\text { kepada Allah }\end{array}$ & 1.000 & .660 \\
$\begin{array}{l}\text { Anda merasa harta Anda bersih setelah } \\
\text { berzakat dan berinfak }\end{array}$ & 1.000 & .681 \\
$\begin{array}{l}\text { Anda senang membantu fakir/ miskin } \\
\text { Anda merasa bersalah saat tidak } \\
\text { membayar zakat atau infak }\end{array}$ & 1.000 & .746 \\
$\begin{array}{l}\text { Anda senang dapat meningkatkan } \\
\text { kondisi ekonomi fakir/miskin }\end{array}$ & 1.000 & .810 \\
\hline Lanjutan lampiran 2.000 & .715 \\
\hline
\end{tabular}

Lanjutan lampiran 2. 
Communalities (lanjutan)

\begin{tabular}{|l|c|c|}
\hline & Initial & Extraction \\
\hline $\begin{array}{l}\text { Anda menyadari bahwa ada hak orang } \\
\text { lain dalam harta Anda }\end{array}$ & 1.000 & .652 \\
$\begin{array}{l}\text { Anda percaya dengan berzakat, Anda } \\
\text { menjadi contoh yang baik bagi orang } \\
\text { lain }\end{array}$ & 1.000 & .687 \\
$\begin{array}{l}\text { Lembaga amil zakat bekerja secara } \\
\text { profesional }\end{array}$ & 1.000 & .843 \\
$\begin{array}{l}\text { Lembaga amil zakat transparan dalam } \\
\text { hal laporan keuangan }\end{array}$ & 1.000 & .659 \\
$\begin{array}{l}\text { Anda merasa nyaman dengan } \\
\text { membayar zakat di lembaga amil zakat } \\
\begin{array}{l}\text { Layanan di lembaga amil zakat } \\
\text { memuaskan }\end{array}\end{array}$ & 1.000 & .753 \\
$\begin{array}{l}\text { Lembaga amil zakat melakukan } \\
\text { sosialisasi melalui media massa, media } \\
\text { elektronik }\end{array}$ & 1.000 & .816 \\
$\begin{array}{l}\text { Lembaga amil zakat melakukan } \\
\text { sosialisasi langsung kepada masyarakat }\end{array}$ & 1.000 & .605 \\
$\begin{array}{l}\text { Bagaimana dengan pemotongan gaji } \\
\text { secara langsung untuk zakat dari } \\
\text { institusi tempat Anda bekerja }\end{array}$ & 1.000 & .437 \\
\hline
\end{tabular}




\section{Lampiran 2. Total Variance Explained}

Total Variance Explained

\begin{tabular}{|c|c|c|c|c|c|c|c|c|c|}
\hline \multirow[b]{2}{*}{ Component } & \multicolumn{3}{|c|}{ Initial Eigenvalues } & \multicolumn{3}{|c|}{ Extraction Sums of Squared } & \multicolumn{3}{|c|}{ Rotation Sums of Squared Loadings } \\
\hline & Total & $\%$ of Variance & Cumulative \% & Total & $\%$ of Variance & Cumulative \% & Total & $\%$ of Variance & Cumulative \% \\
\hline 1 & 6.039 & 24.155 & 24.155 & 6.039 & 24.155 & 24.155 & 4.581 & 18.322 & 18.322 \\
\hline 2 & 4.443 & 17.773 & 41.928 & 4.443 & 17.773 & 41.928 & 3.035 & 12.142 & 30.464 \\
\hline 3 & 1.972 & 7.890 & 49.818 & 1.972 & 7.890 & 49.818 & 2.709 & 10.837 & 41.301 \\
\hline 4 & 1.569 & 6.277 & 56.095 & 1.569 & 6.277 & 56.095 & 2.485 & 9.941 & 51.243 \\
\hline 5 & 1.279 & 5.117 & 61.212 & 1.279 & 5.117 & 61.212 & 1.972 & 7.888 & 59.131 \\
\hline 6 & 1.190 & 4.760 & 65.971 & 1.190 & 4.760 & 65.971 & 1.486 & 5.943 & 65.074 \\
\hline 7 & 1.005 & 4.019 & 69.990 & 1.005 & 4.019 & 69.990 & 1.229 & 4.917 & 69.990 \\
\hline 8 & .927 & 3.707 & 73.698 & & & & & & \\
\hline 9 & .770 & 3.080 & 76.778 & & & & & & \\
\hline 10 & .735 & 2.939 & 79.717 & & & & & & \\
\hline 11 & .615 & 2.461 & 82.179 & & & & & & \\
\hline 12 & .537 & 2.149 & 84.328 & & & & & & \\
\hline 13 & .506 & 2.024 & 86.352 & & & & & & \\
\hline 14 & .465 & 1.860 & 88.213 & & & & & & \\
\hline 15 & .464 & 1.856 & 90.069 & & & & & & \\
\hline 16 & .411 & 1.643 & 91.712 & & & & & & \\
\hline 17 & .354 & 1.415 & 93.128 & & & & & & \\
\hline 18 & .325 & 1.299 & 94.427 & & & & & & \\
\hline 19 & .275 & 1.100 & 95.527 & & & & & & \\
\hline 20 & .254 & 1.017 & 96.544 & & & & & & \\
\hline 21 & .234 & .937 & 97.481 & & & & & & \\
\hline 22 & .212 & .850 & 98.330 & & & & & & \\
\hline 23 & .174 & .698 & 99.028 & & & & & & \\
\hline 24 & .145 & .582 & 99.610 & & & & & & \\
\hline 25 & .098 & .390 & 100.000 & & & & & & \\
\hline
\end{tabular}


Lanjutan lampiran 2.

Rotated Component Matrix ${ }^{a}$

\begin{tabular}{|c|c|c|c|c|c|c|c|}
\hline & Component & & & & & & \\
\hline & 1 & 2 & 3 & 4 & 5 & 6 & 7 \\
\hline $\begin{array}{l}\text { Anda selalu shalat fardhu } 5 \text { kali dalam satu hari } \\
\text { Shalat fardhu berjamaah } 3 \text { kali sehari di masjid } \\
\text { Menurut Anda zakat itu wajib } \\
\text { Anda mampu menghitung zakatnya sendiri } \\
\text { Anda rutin membaca buku-buku agama } \\
\text { Anda rutin hadir di majelis ilmu } \\
\text { Anda percaya dengan semua balasan atas perbuatan } \\
\text { Anda. } \\
\text { Anda mendapatkan kemudahan rezeki setelah } \\
\text { membayar zakat } \\
\text { Lingkungan sekitar Anda menyambut baik saat anda } \\
\text { berzakat } \\
\text { Anda senang disebut dermawan setelah berzakat } \\
\text { Anda merasa iba ketika melihat fakir/miskin } \\
\text { Dengan berzakat atau infak berarti Anda telah } \\
\text { berupaya untuk bersyukur kepada Allah } \\
\text { Anda merasa harta Anda bersih setelah berzakat dan } \\
\text { berinfak } \\
\text { Anda senang membantu fakir/ miskin } \\
\text { Anda merasa bersalah saat tidak membayar zakat atau } \\
\text { infak } \\
\text { Anda senang dapat meningkatkan kondisi ekonomi } \\
\text { fakir/miskin } \\
\text { Anda menyadari bahwa ada hak orang lain dalam harta } \\
\text { Anda } \\
\text { Anda percaya dengan berzakat, Anda menjadi contoh } \\
\text { yang baik bagi orang lain } \\
\text { Lembaga amil zakat bekerja secara profesional } \\
\text { Lembaga amil zakat transparan dalam hal laporan } \\
\text { keuangan } \\
\text { Anda merasa nyaman dengan membayar zakat di } \\
\text { lembaga amil zakat } \\
\text { Layanan di lembaga amil zakat memuaskan } \\
\text { Lembaga amil zakat melakukan sosialisasi melalui } \\
\text { media massa, media elektronik } \\
\text { Lembaga amil zakat melakukan sosialisasi langsung } \\
\text { kepada masyarakat } \\
\text { Bagaimana dengan pemotongan gaji secara langsung } \\
\text { untuk zakat dari institusi tempat Anda bekerja }\end{array}$ & $\begin{array}{l}.850 \\
.895 \\
.762\end{array}$ & $\begin{array}{l}.653 \\
.507\end{array}$ & $\begin{array}{c}.750 \\
.853 \\
.579\end{array}$ & $\begin{array}{l}.669 \\
\\
.810 \\
.792\end{array}$ & $\begin{array}{l}.652 \\
.706\end{array}$ & $\begin{array}{l}.559 \\
.888\end{array}$ & .806 \\
\hline
\end{tabular}

